\title{
Determinants of Entrepreneurship Intention: An Empirical Study from Entrepreneurship Training Program
}

\author{
Nadia Putri ${ }^{1}$, Yulia Eka Riyanti ${ }^{2}$, Deni Darmawati ${ }^{3}$, Karina Echilia $^{4}$, \\ Abdul Khaliq Brutu ${ }^{5}$, Rufita Ulinvia ${ }^{6}$ \\ \{nadiap153@yahoo.com ${ }^{1}$,yuliaekariyan@gmail.com ${ }^{2}$,deni_darmawati@trisakti.ac.id ${ }^{3}$ \} \\ Faculty of Economy and Business, Universitas Trisakti, Jakarta, Indonesia ${ }^{1,2,3}$
}

\begin{abstract}
The purpose of this study is to analyze the effect of personal factors (X1) and family factors (X2) on entrepreneurship intention (Y) moderated by entrepreneurship training $(Z)$. The sample of this research is all students of class 11 SMK Triguna 1956, totaling 30 people. The data used in this study is primary data collected through questionnaires. The data analysis used in this study is multiple linear regression analysis. The results of this study indicate that personal factors had a positive effect on entrepreneurship intention. Family factors had a negative effect on entrepreneurship intention. This research also found that the entrepreneurship training weakens the positive effect of personal factors on entrepreneurship intention. Meanwhile, the entrepreneurship training weakens the negative effect of family factor on entrepreneurship intention. This shows that entrepreneurship training causes students to reconsider their interest in becoming entrepreneurs, because there are many things that must be studied more intensively.
\end{abstract}

Keywords: Personal factors-1; family factors-2; entrepreneurship training-3; entrepreneurship intention-4

\section{Introduction}

The Corona Virus Disease 2019 (Covid-19) outbreak has become a global pandemic since it was established by the World Health Organization (WHO) on March 9, 2020. The total number of Covid-19 cases worldwide until the end of December 2020 reached 83.5 million cases. In Indonesia, the number of Covid-19 cases continues to increase and is overshadowed by new mutations, but the availability of a vaccine is expected to be the main key to assisting the economic recovery process (Report on the Economic Development of Indonesia and the World Quarter IV 2020 Edition Vol. 4, No. 4 February 2021 ISSN 2580-2518). Covid-19 in Indonesia has an impact on economic and social aspects which are marked by increasing mortality and poverty rates, health vulnerabilities, and even soaring unemployment rates due to several companies laying off employment. This raises risks that have an impact on the economy in the form of a decrease in people's purchasing power, a decrease in production and economic transactions and can cause turmoil in society [1]. 
Micro, Small and Medium Enterprises (MSMEs) are the backbone of the Indonesian economy that contribute and have a role in expanding job opportunities and employment (Ministry of Finance, 2019). The Covid-19 pandemic requires entrepreneurs to continue to market their products which were originally conventional, to be more creative by trying to market through social media to maintain their business. This is indicated bya survey conducted by The World Bank IBRD-IDA that as many as $42 \%$ of MSMEs have marketed their products using social media in anticipation of social distancing policies (Ministry of Cooperatives and SMEs of the Republic of Indonesia, 2021).

The role of entrepreneurship can have an influence on economic progress and improving economic conditions in Indonesia. An entrepreneur must have the ability to find and take advantage of opportunities to produce the necessary resources so that they can make a profit [2]. In addition, the positive impact of entrepreneurship is the creation of jobs, thus helping in improving the quality of life, increasing income distribution, utilizing and mobilizing resources to increase to extend national efficiency, and progress government welfare through government programs, such as taxes and others. By becoming an entrepreneur, it is hoped that it can help overcome the problem of unemployment by creating new jobs, but being an entrepreneur is not an easy thing. The Central Bureau of Statistics (BPS) states that graduates of Vocational High Schools (SMK) are still the largest contributor to unemployment compared to graduates of other education levels. Therefore, Vocational Schools are expected to be able to commit to paying attention to the interests of their students' talents, especially in Field Work Practice (PKL) activities to fulfill the needs of students to become professionals in accordance with their fields [3].

Graduates from Vocational High Schools (SMK) are more prepared to take part in the selection of new employees from both the government and private sectors [4]. However, the school does not equip students to understand entrepreneurship, this has an impact on increasing unemployment due to an imbalance between the availability of jobs and the competence of human resources [5]. With students' low entrepreneurship intention, education and direction are needed for students to encourage the entrepreneurial spirit in the younger generation, so that they are not only oriented as job seekers, but can also create fields by fostering interest in becoming entrepreneurs.

According to [6], entrepreneurship intention is the desire, interest, and willingness to work hard or be strong-willed to try optimally to fulfill his life needs without feeling afraid of the risks that will occur, and having a strong will to learn from failure. A person who already has an entrepreneurship intention, has the main capital in the form of a desire to try and encourage in running new things by being able to accept the risks and challenges that will be faced in starting a business. Entrepreneurship intention is also driven by several factors, both internal and external. According to [7], the entrepreneurial spirit will be relatively easier to form through each person from within, and will be more effective when complemented by interacting activities with various external factors. In this case, personal factors are one of the things that can influence entrepreneurial intention which includes the need for achievement, a source of control, and self-confidence [8]. Personal experience can be a guide in doing business, to be careful and minimize mistakes in running the business that will be pioneered.

In addition to personal factors, the entrepreneur background of parents has a significant influence on children's entrepreneurship intentions [9]. Family is the first environment for someone who is able to help development and growth both mentally and physically in life. A conducive family environment and active family interactions can help a person to identify himself and adapt in the life of society and the natural surroundings. In addition, the family environment can also influence an individual in determining his future, one of which is related 
to job selection. Family is an external factor that can affect a person's entrepreneurship intention, parents who are entrepreneurship or will not provide experience to their children [10].

Entrepreneurship education can take place from an early age in a family environment, if entrepreneurial parents can provide training and knowledge to take part in helping from easy jobs to complex jobs, thus making a child trained and inspired to become an entrepreneur so that it affects his intention. for entrepreneurship, through the family an entrepreneurial mindset is formed [11]. Entrepreneurship intention grows and develops well in someone who lives and grows in an entrepreneur's family environment. Support from both parents and the family can be an encouragement and motivation as it can affect the entrepreneurship intention. If the family does not support someone to become an entrepreneur, then the possibility of a person's entrepreneurship intention will be smaller or even have no interest related to it. Research conducted by Santoso \& Alamanda (2021) found that educational factors have a positive effect on entrepreneurship intention. Research conducted by Wahyuningsih (2020) found that personality factors have a positive effect on entrepreneurship intention. Furthermore, research conducted by [14] found that there was a positive and significant influence of the family environment on entrepreneurship intention. Research conducted by Wahyuningsih (2020) found that personality factors have a positive effect on entrepreneurship intention. Furthermore, research conducted by [14]found that there was a positive and significant influence of the family environment on entrepreneurship intention. Research conducted by Wahyuningsih (2020) found that personality factors have a positive effect on entrepreneurship intention. Furthermore, research conducted by [14] found that there was a positive and significant influence of the family environment on entrepreneurship intention.

One of the factors favoring the development of entrepreneurship in a country lies in the role of universities through the implementation of entrepreneurship education [15], [16]. The influence of entrepreneurship education has been considered as one of the important factors for growing and developing entrepreneurial passion, spirit and behavior among the younger generation. Related to the influence of entrepreneurship education, it is necessary to have an understanding of how to develop and encourage the birth of potential young entrepreneurs [16]. Entrepreneurship education in the form of training or work practices will be very useful for the younger generation in helping determine the business to be occupied. In addition, it can also be obtained from the experience of others in the desired field as learning material for entrepreneurship. Therefore, entrepreneurship education can strengthen the influence of personal and family factors on one's entrepreneurship intention.

The purpose of this study is to examine the effect of personal and family factors on entrepreneurship intention moderated by entrepreneurship education. The results of this study found that personal factors have a positive and significant effect on entrepreneurship intention. Meanwhile, family factors do not have a positive effect on entrepreneurship intention. Entrepreneurship education weakens the positive influence of personal factors on entrepreneurship intention. However, entrepreneurship training weakens the negative influence of family factors on entrepreneurship intention. The next discussion in this paper is a description of the literature review and hypothesis development. The next section is the research method, then continued with the results of the analysis and discussion, and closed with conclusions, limitations, and implications. 


\section{Literature Review and Hypothesis Development}

\subsection{Literature Review}

\section{a) Entrepreneurship Intention}

Entrepreneurship intention is a tendency of the heart from within a person in the process of planning, organizing, managing, taking risks and developing the business he creates to achieve goals with desire and courage. Interest in trying aims to create a business field through creative, innovative ideas, and can manage the opportunities that exist by working hard, high spirits because the entrepreneurship intention must look forward in establishing a business [17]. Entrepreneurship intention is also the ability to encourage oneself and do something to meet the needs of life and solve life's problems, advance a business or create a new business with a feeling of pleasure because it brings benefits for him to try. In addition, entrepreneurship also fulfills the needs of life without feeling afraid of the risks that will be faced, and always learns from the failures experienced by developing the business it creates [15].

\section{b) Personal Factor}

Personality is an attitude or style that a person has as a characteristic of the individual that comes from the acceptance of the surrounding environment. Personality can explain positive or negative values in a person. Other personalities that must be possessed when entrepreneurship are goal-oriented, have high self-confidence, have a leadership spirit, hard worker, patient, strong determination and there are many more, which are able to motivate the formation of human resources in managing existing businesses [18]. The entrepreneur spirit that is in a person is a strong determination and will so that he can achieve all goals and plans as expected. In addition, the entrepreneurial spirit that exists in a person will always bring up new ideas and be confident and always optimistic [19].

\section{c) Family Factor}

The family environment is the smallest group in society and also the first environment that affects the behavior of people, especially children. In a family environment, a person will get attention, affection, encouragement and guidance from parents or siblings who can help identify potential and future developments [20]. In addition, the family environment is also a person's first environment in his life. The family environment comprises of guardians, siblings and other closest relatives [20]. In general, the hallmark of a family is the existence of a paired relationship in the marriage bond, the recognition of the existence of children being born, and the existence of economic life in married life.

\section{d) Entrepreneurship Training}

Entrepreneurship training is a training program that discusses aspects of entrepreneurship as an important part in preparing students' competencies and skills [21]. Entrepreneurship training aims to raise awareness that entrepreneurship is a career choice and improve understanding of the process of setting up and managing new businesses (Arasti, Falvarjani and Imanipour, 2012 in [22]). 
In addition, entrepreneurship training is also an entrepreneurial teaching and learning activity which includes the development of knowledge, personal character, skills, and attitudes [23]. Such education is education that is oriented to the formation of an entrepreneurial spirit, namely one who has the courage and willingness to face the problems of life and life naturally, a creative soul to solve these problems, an independent spirit and does not depend on others [24]. The proper implementation of training is training that prioritizes using a participatory approach. In particular, this approach is used to engage the training participants so that they can actively participate in the training process. The participant approach is also found to be more effective as training participants will have a more active and broader role in identifying needs, planning, implementing and evaluating the results of training activities. The material is presented as reinforcement, while much of it is given in the form of discussion, exercise, simulation and/or practice. All assignments or practices requested by the material giver (both individual and group assignments) must be fulfilled as part of the process of achieving graduate competence [25]. Entrepreneurship education can increase insight into entrepreneurship, through attitudes, knowledge, and skills that are useful in overcoming problems when carrying out tasks as entrepreneurs [26]. Learning courses in the field of entrepreneurship is a good assessment [27].

\subsection{Conseptual Framework}

This study examines the effect of personal and family factors on entrepreneurship intention moderated by entrepreneurship training. Therefore, the frame of mind can be described as follows:

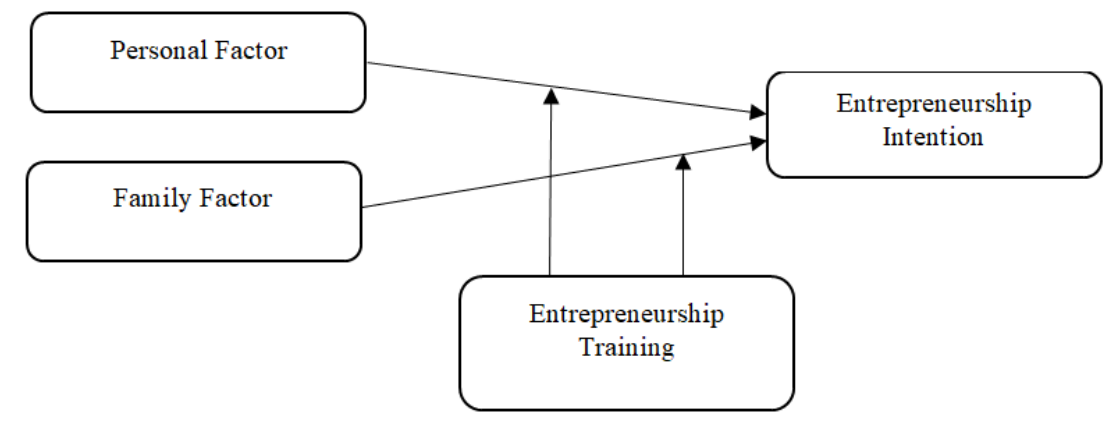

Fig. 1. Conseptual Framework

\subsection{Hypothesis Development}

\section{a) The Influence of Personal Factors on Entrepreneurship intention}

Individual personality characteristics influence entrepreneurial success. The more mature the individual personality, the more equipped individuals are to face all problems and uncertainties in entrepreneurship [8]. Personality traits produce positive attitudes in increasing entrepreneurial intentions [28]. This is supported by research conducted by [29] which found that personality factors influence entrepreneurship intention. In line with Suryantoro's research, [30] found that personality influences entrepreneurship intention. In line with the 
research of [31] found that personality factors affect the entrepreneurship intention. Based on the description above, the first hypothesis is formulated:

$\mathrm{H}_{1}$ : Personal factors have a positive effect on entrepreneurship intention

\section{b) The Influence of Family Factors on Entrepreneurship Intention}

In the family environment, one of which parents will influence their children for their future, one example in terms of choosing a job. Demeanors and exercises of family individuals impact each other both directly and indirectly, for example, parents who are entrepreneurship, it can lead to someone's entrepreneurship intention. If the family supports someone to become an entrepreneur, the higher the interest of a person to become an entrepreneur [20].

This is supported by the research of [14] which found that there was a positive and significant influence of the Family Environment on Entrepreneurship intention. [29] found that the family environment affects the entrepreneurship intention. This is also supported by research conducted by [20] which found that the family environment influences the entrepreneurship intention. Based on the description above, the second hypothesis is formulated:

$\mathrm{H}_{2}$ : Family factors have a positive effect on entrepreneurship intention

c) The Role of Entrepreneurship Training in moderating the effect of personal and family factors on entrepreneurship intention

To support the entrepreneurship intention in students, the role of entrepreneurship education in Vocational High Schools is a must to be given to every student [13]. Knowledge about entrepreneurship obtained from the entrepreneurship training process can be in the form of material understanding of entrepreneurship intention [6]. The higher level of student understanding the entrepreneurship, the higher entrepreneurship intention. The high entrepreneurship intention will progressively grant birth to youthful business visionaries who have imagination and advancement in different areas (Sintya, 2019).

This is supported by research conducted by Maryani, Ariati \& Achmadi (2019) which found that entrepreneurship training has an effect on entrepreneurship intention. In addition, Sintya (2019) found that entrepreneurship education has an effect on entrepreneurship intention. This is in line with Putri (2017) who found the entrepreneurship education had an effect on student entrepreneurship intention. Based on this description, the following hypothesis is formulated:

$\mathrm{H}_{3 \mathrm{a}}$ : Entrepreneurship training strengthens the influence of personal factors on entrepreneurship intention

$\mathrm{H}_{3 b}$ : Entrepreneurship training strengthens the influence of family factors on entrepreneurship intention

\section{Research Methodology}

\subsection{Variable and Measurement}

This study was conducted to test the hypothesis regarding the influence of personal factors and family factors on entrepreneurship intention moderated by entrepreneurship training. This study uses primary data, the source of the data is obtained by distributing questionnaires to all 
training participants, namely the 11th grade students of SMK Triguna 1956 Jakarta. In this study were conducted using multiple linear regression analysis for making conclusions.

a) Independent Variable

The independent variables in this study were personal and family factors.

b) Personal Factor

Personal factor is a characteristic possessed by someone who comes from the surrounding environment (Kurniawan, Khafid \& Pujiati, 2016). Measurement for personal factors uses the formula developed by Nurhalimah (2017) as follows:

Table 1. Personal Factor

\begin{tabular}{ll}
\hline & \multicolumn{1}{c}{ Indicator } \\
\hline FP1 & I am able to solve problems \\
FP2 & I accept the consequences faced \\
FP3 & I accept the risks that occur in entrepreneurship \\
FP4 & I dare to take the risk that will happen \\
FP5 & I believe that with entrepreneurship I can be successful \\
FP6 & I believe the key to success is entrepreneurship \\
FP7 & I am open to customer criticism of my business \\
FP8 & Criticism is input for us to be better. \\
\hline
\end{tabular}

Source: Nurhalimah (2017)

c) Family Factor

Family factor is the second independent variable in this study. The family factor is a small group that exists in society and the first factor that is able to influence a person's behavior (Sintya, 2019). In this study, family factors were measured using the formula developed by Nurhalimah (2017) as follows:

Table 2. Family Factor Indicator

FK1 My parents really support me in entrepreneurship

FK2 My parents motivate me to be an entrepreneur

FK3 My parents provide capital in my business

FK4 The economic situation is getting better with entrepreneurship.

FK5 I have parents who are always supportive.

FK6 I have good communication with parents

FK7 I have a family that wants me to be the best.

FK8 I get more attention from my familySS

Source: Nurhalimah (2017)

d) Dependent Variable

The dependent variable in this study is entrepreneurship intention.

e) Entrepreneurship intention

Entrepreneurship intention is a person's courage and desire to become an entrepreneur (Paramitasari \& Muhyadi, 2016). In this study, entrepreneurship intention is measured by the formula developed by Putri (2020) as follows: 
Table 3. Entrepreneurship intention

\begin{tabular}{cl}
\hline & \multicolumn{1}{c}{ Indicator } \\
\hline MB1 & I am prepared to do anything to ended up an entrepreneur \\
MB2 & My dream job is to become an entrepreneur. \\
MB3 & I will try to establish and develop my own company. \\
MB4 & I have determined to become an entrepreneur in the future. \\
MB5 & I have been thinking very seriously about becoming an entrepreneur. \\
MB6 & I have the intention of becoming an entrepreneur one day. \\
\hline & Source: Putri (2020)
\end{tabular}

f) Moderating Variable

The moderating variable in this study is entrepreneurship training.

g) Entrepreneurship Training

Entrepreneurship training is a training course aimed at improving the process of setting up and managing a business (Arasti et al., 2012 in Kusminatarti et al., 2017). Entrepreneurship training in this study was measured using the formula developed by Blegur \& Handoyo (2020) as follows:

Table 4. Entrepreneurship Training

\begin{tabular}{c|l}
\hline PK1 & $\begin{array}{l}\text { Entrepreneurship training allows me to identify alternative career options. } \\
\text { Through entrepreneurship training, I learned methods for generating basic business ideas. } \\
\text { PK2 } \\
\text { Entrepreneurship education enhances my ability to better understand business opportunities } \\
\text { in my environment. } \\
\text { PK4 }\end{array}$ \\
Entrepreneurship education helps me to solve economic and social problems in my \\
environment in exchange for a fee. \\
PKtrepreneurship training has increased my understanding of the various sources of \\
obtaining funds to start a new business. \\
PK7 & $\begin{array}{l}\text { I have procured the abilities, information and competencies required to set up create and } \\
\text { oversee a modern trade from entrepreneurship education. } \\
\text { Entrepreneurship training increased my awareness of the rights and duties of entrepreneurs } \\
\text { and their commitment to stakeholders. }\end{array}$ \\
Entrepreneurship training allows me to identify the characteristics of a successful \\
entrepreneur (such as risk taking, proactive, innovative, etc.). \\
Entrepreneurship training has increased my awareness of the various forms of business I \\
can manage (such as sole proprietorships, partnerships, etc.). \\
Entrepreneurship training gave me a feeling of independence.
\end{tabular}
Source: Blegur \& Handoyo (2020)

\subsection{Research Sample}

The population is a group, people, events, or interesting things where the researcher wants to make an opinion [38]. The data used in this study are primary data obtained through the distribution of questionnaires to 11th grade students of SMK Triguna 1956. So the population in this study was 30 people. The data analysis used in this research is multiple linear regression analysis.

\subsection{Data Analysis Method}


The data analysis method used in this study is a quantitative data using multiple regression analysis, by accommodating validity tests, reliability tests, classical assumption tests and hypothesis testing. The regression equation 1 in the study is stated as follows:

$\mathrm{MB}=\alpha+\beta_{1} \mathrm{X}_{1}+\beta_{2} \mathrm{X}_{2+1} \mathrm{X}_{1} * \mathrm{Z}+\beta_{2} \mathrm{X}_{2} * \mathrm{Z}+\mathrm{e}$

Information:

$\mathrm{MB}=$ Entrepreneurship intention

$\mathrm{PF}=$ Personal Factor

$\mathrm{FF}=$ Family Factor

$\mathrm{EE}=$ Entrepreneurship Education

e $\quad=$ Error

\section{Analysis and Discussion}

In this study, the validity of the data has been tested and shows that all questions in the questionnaire are declared valid. Furthermore, in this study a reliability test has been carried out and the data is declared reliable. In addition, in this study, classical assumption tests were also carried out including normality test, heteroscedasticity test, autocorrelation test and multicollinearity test. Of all the classical assumption tests, there is one test that has a problem, namely the multicollinearity test. However, these results can be ignored and research can be continued. The disturbance in the multicollinearity test is caused by the interaction between the independent variable and the moderating variable.

\subsection{Analysis Results}

Based on the results of hypothesis testing, it can be seen in the following table:

Table 5. Analysis Results

\begin{tabular}{|c|c|c|c|}
\hline Variable & Coefficient & Prob. & Results \\
\hline $\mathrm{C}$ & 7.577 & .042 & - \\
\hline Personal Factor & 3.328 & .015 & Accepted \\
\hline Family Factor & -4.222 & .040 & Rejected \\
\hline Entrepreneurship training & -1.613 & .076 & \\
\hline Entrepreneurship Training * Personal Factor & -.689 & .034 & Rejected \\
\hline Entrepreneurship Training * Family Factor & 1.096 & .027 & Rejected \\
\hline $\begin{array}{l}\text { Adjusted R-Squared } \\
\text { Probability (F-Statistic) } \\
\text { F-Stat }\end{array}$ & & & $\begin{array}{l}\text { Accepted } \\
.639 \\
1.253 \\
.000 \\
\end{array}$ \\
\hline
\end{tabular}

Source: Data processed 2021

$\mathrm{H}_{1}$ : The Influence of Personal Factors on Entrepreneurship intention

The results of the data processing of the personal factor coefficient of 3.328, meaning that the theory test which states there is a positive influence between personal factor variables on entrepreneurship intention is proven (passed the theory test). So that it can be continued into 
statistical tests. From the results of statistical tests obtained p-value of $0.015(0.015<0.05)$. Thus it can be concluded that $\mathrm{H}_{0}$ is rejected and $\mathrm{H} 1$ is accepted.

$\mathrm{H}_{2}$ : The Influence of Family Factors on Entrepreneurship intention

The results of the data processing of the family factor coefficient of -4.222 , meaning that the theory test which states that there is a positive influence between family factor variables on entrepreneurship intention is not proven. So the $\mathrm{p}$-value for this variable was not analyzed further. Based on the results, it can be concluded that $\mathrm{H}_{0}$ is accepted and $\mathrm{H} 2$ is rejected.

$\mathrm{H}_{3 \mathrm{a}}$ : The Role of Entrepreneurship Training in Moderating the Effect of Personal Factors on Entrepreneurship intention

The result of data processing the interaction coefficient between entrepreneurship training and personal factors is -0.689 , meaning that the theory test which states that the role of entrepreneurship training strengthens the positive influence between personal factor variables on entrepreneurship intention is not proven. So the p-value for this variable was not analyzed further. Based on the results, it can be concluded that $\mathrm{H}_{0}$ is accepted and $\mathrm{H} 4$ is rejected.

$\mathrm{H}_{3 \mathrm{~b}}$ : The Role of Entrepreneurship Training in Moderating the Effect of Family Factors on Entrepreneurship intention

The result of data processing the interaction coefficient between entrepreneurship training and family factors is 1.096 , meaning that the theory test which states that the role of entrepreneurship training strengthens the positive influence between family factor variables on entrepreneurship intention is proven (passed the theory test). So that it can be continued into statistical tests. From the results of statistical tests obtained p-value of $0.027 \quad(0.027<0.05)$. Thus it can be concluded that $\mathrm{H}_{0}$ is rejected and $\mathrm{H} 5$ is accepted.

\subsection{Discussion}

The results of testing the first hypothesis shows that personal factors positively influence entrepreneurship intention. This result is supported by research conducted by [29] who found that personality factors influence the entrepreneurship intention. In line with [30] found that personality influences entrepreneurship intention. In line with the research of [31] found that personality factors affect the entrepreneurship intention. This is because individual personality characteristics influence entrepreneurial success. The more mature the individual personality, the more equipped individuals are to face all problems and uncertainties in entrepreneurship [8]. Personality traits produce positive attitudes in increasing entrepreneurial intentions.

The results of testing the second hypothesis indicate that family factors have no effect on entrepreneurship intention. This result contradicts the research conducted by [14] which found that there was a positive and significant influence of the Family Environment on Entrepreneurship intention. However, the results of this study are supported by research conducted by [39] which found that the family environment did not simultaneously affect the entrepreneurship intention. This result is in line with the findings in [40] study which found that family had no influence on entrepreneurship intention.

Family factors have no effect on entrepreneurship intention is due to the tendency of students to prefer to become a State Civil Apparatus or work for large companies that provide high salaries every month, when graduating from Vocational High School [41]. This is because, to become an entrepreneur, one must be able to accept and face all the problems and uncertainties in entrepreneurship [8]. The results of the third hypothesis testing show that entrepreneurship training is not moderate the influence of personal factors on entrepreneurship intention. This result is in contrast to the research conducted by [13] which found that personality factors have a positive and significant effect on entrepreneurship intention. 
However, this study is in line with the research conducted by [42] which found that educational factors did not significantly influence student entrepreneurship intention. In addition, this study is supported by research conducted by [14] which found that there was no positive effect of entrepreneurship education on entrepreneurship intention.

This is because, In addition to entrepreneurship education, training in entrepreneurship is required by holding seminars on entrepreneurship and entrepreneurship, as seminars inviting successful entrepreneurs provide motivation to themselves for entrepreneurship while entrepreneurship practices will provide experience and can be a driving force for entrepreneurship intention [20]. The results of testing the fourth hypothesis indicate that entrepreneurship training is able to moderate the influence of family factors on entrepreneurship intention. This research is supported by research conducted by [33] who found that entrepreneurship education has an effect on student entrepreneurship intention. This is in line with the research conducted by [12] who found that entrepreneurship education has an effect on entrepreneurship intention. In addition, these results are supported by research conducted by [43] which found that education will provide a large stimulus in relation to entrepreneurship intention.

\section{Conclusions}

Based on the comes about of the analysis and discussion depicted within the past chapter, the conclusions of this study are:

1. Personal factors influence the entrepreneurship intention in students of SMK Triguna 1956.

2. Family factors do not affect the entrepreneurship intention in students of SMK Triguna 1956.

3. Entrepreneurship training has no effect on entrepreneurship intention in students of SMK Triguna 1956.

4. Entrepreneurship training was not able to moderate the influence of personal factors on the entrepreneurship intention in students of SMK Triguna 1956.

5. Entrepreneurship training was able to moderate the influence of family factors on entrepreneurship intention in students of SMK Triguna 1956.

\section{Implications}

This research has implications for providers of entrepreneurship education or training. In organizing entrepreneurship education or training, it is better to add elements of practice, so that participants can gain entrepreneurial experiences which will further encourage participants to have an entrepreneurial desire. Based on the conclusions stated above, the implications that can be proposed are:

1. For literature: this research is expected to enrich the literature, related to personal factors.

2. For entrepreneurship education providers: although entrepreneurship education does not significantly influence the entrepreneurship intention, it is hoped that the entrepreneurship training providers will provide more innovation in learning and provide motivation about successful entrepreneurship so that entrepreneurship training will affect students' entrepreneurship intention.

3. Policy: for the Ministry of Cooperatives and SMEs (Small and Medium Enterprises), standardize appropriate entrepreneurship training. 


\section{References}

[1] T. P. Christy, "Legalitas Perusahaan Penanaman Modal Asing Untuk Mendatangkan Tenaga Kerja Asing Ke Indonesia Di Tengah Pandemi Covid-19 (Studi Kasus: PT. PMA Virtue Dragon Nickel Industry)," Universitas Airlangga, 2020.

[2] A. Mutiarasari, "Peran Entrepreneur Meningkatkan Pertumbuhan Ekonomi dan Mengurangi Tingkat Pengangguran,” Dinar J. Prodi Ekon. Syariáh, vol. 1, no. 2, pp. 51-75, 2018.

[3] N. Maryanti, "Siswa SMK Siap Hadapi Revolusi Industri 4.0 (Kajian Praktis Smk Di Provinsi Sumatera Selatan)," 2019.

[4] F. Aryanto and F. A. Muslihudin, "Sistem Pendukung Keputusan Menentukan Sekolah Menengah Kejuruan (Smk) Unggulan Di Wilayah Lampung Tengah Menggunakan Metode Topsis," J. TAM (Technology Accept. Model., vol. 5, 2015.

[5] M. H. Fikri, J. P. R. Harahap, and N. A. Dongoran, "Kewirausahaan Pemuda Dalam Meningkatkan Kualitas Pemuda Di Desa Medan Senembah Kecamatan Tanjung Morawa," 2020.

[6] B. Anggraeni and Harnanik, "engaruh Pengetahuan Kewirausahaan dan Lingkungan Keluarga terhadap Minat Berwirausaha Siswa Kelas XI SMK Islam Nusantara Comal Kabupaten Pemalang," J. Pendidik. Ekon. Din. Pendidik. Vol. X No, 2015.

[7] E. Suherman, Desain Pembelajaran Kewirausahaan. Bandung: Alfa Beta, 2010.

[8] L. Indriyani and Margunani, "Pengaruh Kepribadian, Pendidikan Kewirausahaan, dan Lingkungan Keluarga Terhadap Minat Berwirausaha," Econ. Educ. Anal. J., vol. 7, no. 3, pp. 848-862, 2018.

[9] A. Suyatno and M. Muhtarom, "Pengaruh Lingkungan Keluarga dan Pembelajaran Kewirausahaan Terhadap Intensi Technopreneurship Mahasiswa Manajemen Ilmu Komputer," J. Inf. Politek. Indonusa Surakarta, vol. 4, no. 1, pp. 1-8, 2018.

[10] A. Wibowo, "Dampak Pendidikan Kewirausahaan bagi Mahasiswa," AJEFB Asian J. Entrep. Fam. Bus., vol. 1, no. 1, pp. 1-14, 2017.

[11] R. A. Chandra and H. Budiono, "Pengaruh Pendidikan Kewirausahaan Terhadap Niat Berwirausaha Yang Dimediasi Efikasi Diri Mahasiswa Manajemen,” J. Manajerial Dan Kewirausahaan, vol. 1, no. 4, pp. 645-655, 2019.

[12] T. A. Santoso and V. Alamanda, "Pengaruh Pendidikan Kewirausahaan Dan Efikasi Diriterhadap Minat Berwirausahasiswa Smk Di Kota Semarang," ECONBANK J. Econ. Bank., vol. 3, no. 1, pp. 19-26, 2021.

[13] R. Wahyuningsih, "Pengaruh Pendidikan Kewirausahaan dan Lingkungan Keluarga Terhadap Minat Berwirausaha Mahasiswa STKIP PGRI Jombang," J. Kependidikan J. Has. Penelit. dan Kaji. Kepustakaan di Bid. Pendidikan, Pengajaran dan Pembelajaran, vol. 6, no. 3, pp. 512-521, 2020.

[14] I. Chalik and S. Rahayu, "Faktor - Faktor Yang Mempengaruhi Minat Berwirausaha (Studi Kasus Mahasiswa Prodi Akuntansi UISU)," Semin. Nas. Sains Teknol. Inf., 2018.

[15] J. S. Hendrawan and H. Sirine, "Pengaruh Sikap Mandiri, Motivasi, Pengetahuan Kewirausahaan Terhadap Minat Berwirausaha (Studi Kasus pada Mahasiswa FEB UKSW Konsentrasi Kewirausahaan)," AJIE-Asian J. Innov. Entrep., vol. 2, no. 3, pp. 291-314, 2017.

[16] A. A. G. M. Suarjana and L. M. Wahyuni, "Faktor Penentu Minat Berwirausaha Mahasiswa (Suatu Evaluasi Pembelajaran)," J. Bisnis dan Kewirausahaan, vol. 13, no. 1, pp. 11-22, 2017. 
[17] F. Paramitasari and M. Muhyadi, "Pengaruh Motivasi Berwirausaha Dan Pengetahuan Kewirausahaan Terhadap Minat Berwirausaha Siswa Kelas Xi Kompetensi Keahlian Administrasi Perkantoran SMK N 1 Bantul," J. Pendidik. Adm. Perkantoran, vol. 5, no. 3, pp. 239-248, 2016.

[18] O. A. Diana and D. T. Kurniawan, "). Pengaruh Kepribadian Terhadap Intensi Berwirausaha Dalam Bidang Digital (Techno-Entrepreneur) Pada Mahasiswa Yang Telah Menempuh Mata Kuliah Kewirausahaan Di Universitas Negeri Malang," 2020.

[19] T. Y. Rukmana, "Analisis Faktor-Faktor yang Mempengaruhi Sikap Kewirausahaan," JUPE, vol. 6, no. 2, pp. 8-11, 2018.

[20] N. M. Sintya, "Pengaruh Motivasi, Efikasi Diri, Ekspektasi Pendapatan, Lingkungan Keluarga, Dan Pendidikan Kewirausahaan Terhadap Minat Berwirausaha Mahasiswa Jurusan Akuntansi Di Universitas Mahasaraswati Denpasar," J. Sains, Akunt. Dan Manaj., vol. 1, no. 1, pp. 37-380, 2019.

[21] M. Saroni, Mendidik dan Melatih Entrepreneur Muda. Jakarta: Arus Media, 2012.

[22] I. Firmansyah, N. N. Wahid, A. R. Fadillah, and Kusmayadi, "Analisis Kinerja Bank Syariah Dengan Maqashid Syariah Index (MSI) Dan Profitabilitas,” J. Akunt., vol. 13, no. 1, pp. 1-9, 2018.

[23] A. Kusmintarti, N. I. Riwajanti, and A. Asdani, "Sikap Kewirausahaan Memediasi Pengaruh Pendidikan Kewirausahaan Terhadap Intensi Kewirausahaan,” J. Ris. dan Apl. Akunt. dan Manaj., vol. 2, no. 4, pp. 45-54, 2017.

[24] T. E. Fathiyannida and T. Erawati, "Pengaruh Pendidikan Kewirausahaan, Motivasi Berwirausaha, Lingkungan Keluarga dan Ekspektasi Pendapatan terhadap Minat Berwirausaha Mahasiswa Akuntansi (Studi Kasus pada Mahasiswa Aktif dan Alumni Prodi Akuntansi Fakultas Ekonomi Universitas Sarjanawiyata," J. Ilm. Akunt. dan Finans. Indones., vol. 4, no. 2, pp. 83-94, 2018.

[25] B. R. Purnomo, "Efektivitas Pelatihan Kewirausahaan Dalam Meningkatkan Pengetahuan Dan Motivasi Berwirausaha Pada Penyandang Tunarungu," Ekspektra, J. Manaj. dan Bisnis, vol. 1, no. 1, pp. 21-30, 2017.

[26] N. P. A. A. Wedayanti and I. G. A. K. Giantari, "Peran Pendidikan Kewirausahaan dalam Memediasi Pengaruh Norma Subyektif terhadap Niat Berwirausaha," E-Jurnal Manaj. Unud, vol. 5, no. 1, pp. 533-560, 2016.

[27] U. Choiriyah, "Pengaruh pembelajaran mata kuliah kewirausahaan terhadap intensi keiwrausahaan," J. Res. Gate, pp. 53-60, 2018.

[28] T. Karabulut, "Personality Traits on Entrepreneurial Intention," Procedia Soc. Behav., vol. 229, pp. 12-21, 2016.

[29] D. A. Luzfia and I. M. B. Dwiarta, "Pengaruh Kepribadian Wirausaha, Motivasi Berwirausaha, Dan Lingkungan Keluarga Terhadap Minat Berwirausaha Pada Mahasiswa Prodi Manajemen Angkatan 2017 Di Universitas Adi Buana Surabaya,”J. Sustain. Bus. Res., vol. 2, no. 1, pp. 133-141, 2021.

[30] E. Suryantoro, S. I. Mulyono, and M. B. N. Ariani, "Faktor-Faktor yang Mempengaruhi Minat Berwirausaha Mahasiswa Di Lingkungan Kecamatan Beji Depok," JEMASI J. Ekon. Manaj. dan Akunt., vol. 16, no. 2, pp. 77-88, 2020.

[31] A. H. Kamal and N. Toyyibah, "Analisis Faktor-Faktor Yang Mempengaruhi Minat Berwirausaha Santri Pondok Pesantren," At-Taqaddum, vol. 12, no. 1, pp. 75-90, 2020.

[32] H. Maryani, N. Asriati, and Achmadi, "Terhadap Minat Berwirausaha Penghuni Lapas Perempuan," Khatulistiwa, vol. 8, no. 10, pp. 1-10, 2019.

[33] N. L. W. W. Putri, "Pengaruh Pendidikan Kewirausahaan Terhadap Minat Mahasiswa Untuk Berwirausaha Pada Mahasiswa Pendidikan Ekonomi Universitas Pendidikan 
Ganesha," J. Pendidik. Ekon. Undiksha, vol. 9, no. 1, pp. 137-148, 2017.

[34] A. Kurniawan, M. Khafid, and A. Pujiati, "Pengaruh Lingkungan Keluarga, Motivasi, dan Kepribadian Terhadap Minat Wirausaha Melalui Self Efficacy," J. Econ. Educ., vol. 5, no. 1, pp. 100-109, 2016.

[35] Nurhalimah, "Pengaruh Pengetahuan Kewirausahaan, Faktor Keluarga Dan Faktor Kepribadian Terhadap Minat Berwirausaha Pada Mahasiswa Manajemen Konsentrasi Kewirausahaan S-I Manajemen Fakultas Ekonomi Dan Bisnis Universitas Sumatera Utara," Universitas Sumatera Utara, 2017.

[36] A. Putri, "Pengaruh Sikap, Norma Subjektif, Persepsi Kontrol Perilaku Dan Religiusitas Terhadap Intensi Kewirausahaan Dengan Pendidikan Kewirausahaan Sebagai Variabel Moderasi,” Institut Agama Islam Negeri Salatiga, 2020.

[37] A. Blegur and E. Handoyo, "Pengaruh Pendidikan Kewirausahaan, Efikasi Diri Dan Locus Of Control Terhadap Intensi Berwirausaha," J. Manajerial dan Kewirausahaan, vol. 2, no. 1, pp. 51-61, 2020.

[38] U. Sekaran and R. Bougie, Research Methods For Business: A Skill Building Approach. New York: John Wiley \& Sons, 2016.

[39] B. Kumara, "Analisis Faktor Yang Mempengaruhi Minat Berwirausaha Dengan Menggunakan Media Sosial," J. Ilm. Mhs. Ekon. Manaj., vol. 5, no. 4, pp. 806-820, 2020.

[40] M. E. Astuti, "Pengaruh Keluarga, Etnis, Kepribadian,Gender, Dan Teman Sebaya Terhadap Minat Berwirausaha," J. Bina Manaj., vol. 9, no. 2, pp. 162-183, 2021.

[41] K. S. Damayanthi, "Pengaruh Norma Subyektif, Sikap Pada Perilaku, Presepsi Kontrol Perilaku Terhadap Niat Melakukan Pengungkapan Kecurangan (Whistleblowing)," Universitas Pendidikan Ganesha Singaraja, 2017.

[42] Tarjo, M. Nasir, and Darwanto, "Analisis Faktor-Faktor Yang Mempengaruhi Minat Mahasiswa Berwirausaha Pada Sekolah Tinggi Ilmu Administrasi Setih Setio Muara Bungo.," 2020.

[43] W. Bharata, "Pengaruh Pendidikan Kewirausahaan dan Motivasi Usaha terhadap Minat Berwirausaha," J. Ekon. dan Manaj., vol. 2, no. 2, pp. 98-114, 2019.

[44] "Kementerian Keuangan. (2019). Merekam Pandemi Covid-19 dan Memahami Kerja Keras Pengawal APBN."

[45] "Kementerian Koperasi dan UKM Republik Indonesia. (2021). Terhubung Secara Digital, UMKM Sektor Kuliner Tetap Bertahan Di Saat Pandemi. Nomor: 157/Press/SM 3.1/V/2021."

[46] "Kementerian PPN/Bappenas. Laporan Perkembangan Ekonomi Indonesia dan Dunia Triwulan IV Tahun 2020. Edisi Vol. 4, No. 4 Februari 2021 ISSN 2580-2518.” 